\title{
Do the interactions between coital frequency, cervical length, and urogenital infection affect obstetric outcomes?
}

\author{
Koitus sıklı̆̆ı, servikal uzunluk ve ürogenital enfeksiyonların \\ etkileşimleri obstetrik sonuçları etkiler mi?
}

\author{
Yiğit Çakıroğlu1 1 , Şeyda Çalışkan², Emek Doğer1 ${ }^{1}$, Şule Yıldırım Köpük1, Devrim Dündar3 ${ }^{3}$ Eray Çalışkan1 \\ ${ }^{1}$ Kocaeli University Faculty of Medicine, Department of Obstetrics and Gynecology, Kocaeli, Turkey \\ 2Sakarya University Faculty of Medicine Education and Research Hospital, Department of Clinical Microbiology, Sakarya, Turkey \\ ${ }^{3}$ Kocaeli University Faculty of Medicine, Department of Clinical Microbiology, Kocaeli, Turkey
}

\begin{abstract}
Objective: To determine whether interactions between coital frequency, cervical length, and urogenital infection affect obstetric outcomes.

Materials and Methods: A total of 268 unselected pregnant women were recruited in the study. The study population consisted of four groups of women: group 1 ( $n=203$ ) screened negative for bacterial vaginosis (BV) both in the first and second trimesters; group 2 ( $n=18$ ) screened negative for BV in the first trimester but positive in the second trimester; group $3(n=33)$ screened positive for BV in the first trimester but negative in the second trimester; and group $4(\mathrm{n}=14)$ screened positive for BV both in the first and second trimesters. Urine culture, cervico-vaginal cultures, and bacterial vaginosis were screened between 11-14 weeks and 20-24 weeks.

Results: Two hundred fifty women were eligible for analysis in the study after lost-to-follow up patients were excluded. Previous abortion $\geq 1$ and previous preterm delivery at 24-34 weeks $\geq 1$ were statistically significantly higher in group 2 . The number of patients who were diagnosed as having preterm premature rupture of membranes (PPROM) was statistically significantly higher in group 4 . Sexual intercourse during the first trimester, cervical length during the second trimester, and history of preterm birth (PTB) were statistically significant risk factors for preterm birth <37 weeks (1.27; (1.12-1.44); 5.33; (1.84-15.41); 6.95; (1.58-30.54), respectively).
\end{abstract}

Conclusion: Presence or treatment of BV did not influence rates of PTB. The probability of PPROM would be higher in patients who are BV positive both in the first and second trimesters. J Turk Soc Obstet Gynecol 2015;2:66-70

Key Words: Preterm birth, urogenital infection, bacterial vaginosis, cervical length, coital frequency

Özet

Amaç: Koitus sıklığı, serviks uzunluğu ve ürogenital enfeksiyon varlığı ve değişkenlerin etkileşimlerinin obstetrik sonuçlara etkileri.

Gereç ve Yöntemler: Çalışmamıza 268 gebe kadın dahil edildi. Dört gruba ayrıldı; grup l ( $\mathrm{n}=203)$ hem ilk hem ikinci trimesterde bakteriyel vajinoz (BV) taramasında negatif, grup $2(\mathrm{n}=18)$ ilk trimesterde negatif, ikinci trimesterde pozitif, grup $3(\mathrm{n}=33)$ ilk trimesterde pozitif, ikinci trimesterde negatif, grup $4(n=14)$ her iki trimesterde pozitif saptanan hastalardan oluşturulmuştur. On bir-14 gh ve 20-24 gebelik haftalarında idrar kültürleri serviko-vajinal kültürler ve bakteriyel vajinoz taraması yapilmıştır.

Bulgular: Analizler kalan 250 kadın ile yapıldı. Abortus sayısı $\geq 1$ ve 24.-34. haftalar arası preterm doğumu $\geq 1$ olan hastalar grup 2'de anlamlı yüksek; PPROM tanısı alan hasta sayısı ise grup 4'de anlamlı yüksek saptandı. İlk trimesterde cinsel ilişki, ikinci trimesterde ölçülen serviks uzunluğu ve preterm doğum öyküsü sırası ile istatiksel olarak 37 gh'den önce preterm doğum için önemli risk faktörleri olarak saptanmıştır (1,27; (1,12-1,44); 5,33; (1,84$15,41) ; 6,95 ;(1,58-30,54)$ sirasiyla).

Sonuç: BV varlı̆̆ ve tedavisi preterm doğum oranını etkilememekte. Birinci ve ikinci trimesterde BV pozitif hastalarda PPROM artmakta. İlk trimesterdeki koitus sıklı̆̆ı, ikinci trimesterde ölçülen servikal uzunluk ve preterm doğum öyküsü preterm doğum oranlarını etkileyen değişkenlerdir. J Turk Soc Obstet Gynecol 2015;2:66-70

Anahtar Kelimeler: Preterm doğum, ürogenital enfeksiyon, bakteriyal vajinoz, servikal uzunluk, koitus sıklığ1

\section{Introduction}

Preterm birth (PTB) has been defined as birth before 37 weeks of gestation and is the leading cause of neonatal mortality and morbidity(1). PTB can be divided into spontaneous or induced for maternal and fetal indications. There are multiple etiologic factors that may result in spontaneous preterm birth, including

Address for Correspondence/Yazışma Adresi: Yiğit Çakıroğlu, MD,

Kocaeli University Faculty of Medicine, Department of Obstetrics and Gynecology, Kocaeli, Turkey

Phone: +902623038400 E-mail: dryigit1@yahoo.com

Received /Geliş Tarihi : 19.02.2015

Accepted/Kabul Tarihi : 24.05.2015 
genital tract infections(2). The mechanism responsible for PTB in pregnant women with genital tract infections might be ascending bacteria from the vagina to the chorioamniotic membranes and amniotic fluid(3).

Among the microorganisms responsible for genital tract infections, bacterial vaginosis is the most commonly-associated microorganism-related clinical entity(4). The prevalence of BV has been reported about to be 50\% in pregnant women and 15-30\% in non-pregnant women $(5,6)$. It is hard to investigate to the real prevalence and reported prevalence covers a wide range because most of cases of BV are asymptomatic and the populations that have been investigated were highly selected groups.

The effect of coitus on the outcome of pregnancies remains inconclusive. Some studies have reported no relationship with coital activity and $\operatorname{PTB}(7,8)$. Read et al. reported no association between frequent sexual intercourse and PTB, but contrary to previous authors, they reported an increased risk of PTB in the presence of microorganisms $(9)$.

Either prostaglandin in semen might have a direct effect on the cervix, or coital activity might influence bacterial colonization and result in $\mathrm{PTB}(10)$.

Cervical length assessment via ultrasound can be performed for the prediction of PTB in the first and/or second trimesters(11). Evaluation of cervical length in patients with a history of PTB or in asymptomatic patients might have small differences(12). It is not yet clear whether the presence or absence of a vaginal microorganism might have effects on cervical shortening.

In our study, we aimed to determine whether interactions between coital frequency, cervical length, and urogenital infection affected obstetric outcomes.

\section{Materials and Methods}

A total of 268 unselected pregnant women who were admitted to the obstetrics unit of a tertiary center at at Kocaeli University between July 2007 and September 2011 were invited to participate in the study. The general PTB rate was $12.7 \%(13)$. The sample size needed to recruit was calculated as $\mathrm{t} 2 * \mathrm{pq} / \mathrm{d} 2$ with a $95 \%$ probability to predict this prevalance $(1.962 * 0.1 * 0.9 / 0.052=140)$. The minimum number of patients to be recruited for the study was 140 according to the formula and we recruited 250 patients. Two hundred fifty women were eligible for analysis in the study after the lost-to-follow-up patients were excluded. The local ethics committee approved the study. Written informed consent was obtained from all the patients who participated in the study.

In this study, the primary outcome measure was to determine whether interactions between coital frequency, cervical length, and urogenital infection affected obstetric outcomes.

Criteria for enrollment included all the healthy pregnant women who were admitted during the first trimester. Exclusion criteria included: 1) multifetal pregnancy, 2) intrauterine fetal death, 3) fetal abnormality, and 4) systemic maternal disease. Women with a prior PTB were not excluded from the study.
After patients were evaluated according to the inclusion and exclusion criteria, a total of 268 patients were investigated. The study population consisted of four groups of women: women who screened negative for bacterial vaginosis both in the first and second trimesters; (group 1; n=203), those who screened negative for bacterial vaginosis in the first trimester but positive in the second trimester (group $2 ; n=18$ ), those who screened positive for bacterial vaginosis in the first trimester but negative in the second trimester (group 3; n=33); and those who screened positive for bacterial vaginosis both in the first and second trimesters (group 4; $n=14$ ). Data analysis was performed after excluding patients who were lost-to-follow-up (6 patients in group 1, five patients in group 2, four patients in group 3, and three patients in group 4).

All patients underwent gynecologic examination with a sterile speculum and were investigated for vaginal discharge. Urine culture, cervico-vaginal cultures, and bacterial vaginosis were screened between 11-14 weeks and 20-24 weeks. A polyester swab taken from the junction of the upper third and lower two thirds of the lateral vaginal wall was rolled on a glass slide. The slides were Gram stained and interpreted in accordance with the criteria of Nugent et al.(14). Bacterial vaginosis was diagnosed if the Gram stain score was 7 to 10 . Control vaginal samples were obtained one week after completion of the therapy. Patients with bacterial vaginosis were treated with ornidazole $500 \mathrm{mg}$ for 5 days (Ornisid, Abdi İbrahim, Turkey). Vaginal swabs were directly inoculated onto Sabouraud dextrose agar (SDA) plates (Oxoid), which were incubated at $37{ }^{\circ} \mathrm{C}$ for $48 \mathrm{~h}$ to isolate Candida spp. All strains of Candida spp. were identified based on the germ tube test, and morphologic characteristics on Cornmeal Tween-80 agar and API 20C AUX system (BioMerieux). Ultrasonographic examinations were performed with (Medison Sonoace 8x Ultrasound Machine, Inc., 4-8 MHz) a transvaginal probe. A single specialist (EC) performed the measurements in order to eliminate the possibility for interobserver variability in measurement technique. The specialist was blinded to the women's previous cervical length records. After the patient emptied her bladder, she was placed in the lithotomy position. Transvaginal ultrasonographic measurements of the cervix were made with a standard technique, as previously described by Iams et al.(15). The internal cervical os was identified using a sagittal plane view, and the calipers were placed at the furthest points between the internal and external cervical os. When funneling was present, we measured the distance over which the endocervical walls were juxtaposed. Three measurements were recorded for each and the shortest measurements were used. According to the trial protocol, cervical length was measured first at 11-14 weeks corresponding to routine first trimester nuchal translucency screening, the second was at 18-20 weeks corresponding to the triple test and abnormality screening, and lastly at 28-32 weeks of gestation.

The statistical analysis of the data was performed using the Statistical Package for Social Sciences for Windows (SPSS, 
Chicago, IL, USA). Results were reported as mean \pm standard deviation and percentages. Chi-square test was used to compare categorical variables. Student's T-test was used for comparing continuous variables. Binary logistic regression analysis first with Enter and then with forward Wald methods were used to determine risk factors of PTB ( $<37$ weeks of gestation) as a dicotomous outcome variable. The equation was calculated by independent continous variables such as mean coital frequency/week between admission to 14 weeks, mean coital frequency/week between 14 weeks to 28 weeks and categorical variables such as cervical length $\geq 30 \mathrm{~mm}$ or $<30$ $\mathrm{mm}$ at 11-14 weeks, cervical length $\geq 30 \mathrm{~mm}$ or $<30 \mathrm{~mm}$ at 18-20 weeks, presence or absence of an urinary infection in the first and second trimesters, vaginal symptoms in the first and second trimesters, candidial infection in the first and second trimesters, bacterial vaginosis in the first and second trimesters

Table 1. Maternal variables according to the groups (values are $\mathrm{n}$, mean ( \pm standard deviation) or $\mathrm{n} / \mathrm{N}(\%)$ ).

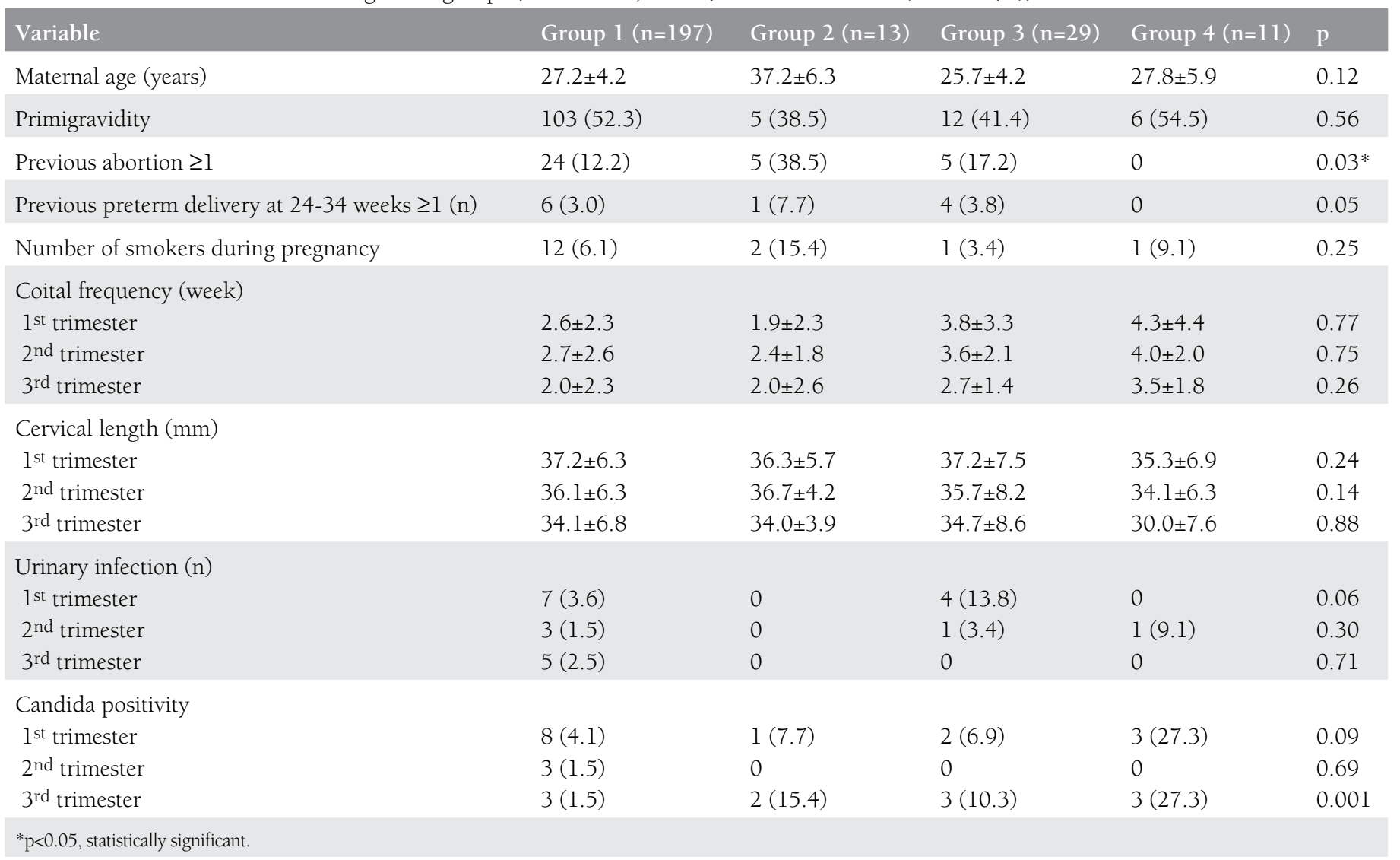

Table 2. Maternal and fetal variables according to data of women who were screened negative for bacterial vaginosis both in the first and second trimesters shortened as (-/-) for group 1, group $2(-/+)$, group $3(+/-)$ and group $4(+/+)$ (values are n, mean $( \pm$ standard deviation) or n/N (\%)).

\begin{tabular}{|c|c|c|c|c|c|}
\hline Variable & Group $1(n=197)$ & Group $2(n=13)$ & Group $3(n=29)$ & Group $4(n=11)$ & $\mathrm{p}$ \\
\hline Gestational age at delivery & $38.5 \pm 2.1$ & $39.0 \pm 1.1$ & $38.1 \pm 3.0$ & $38.1 \pm 2.2$ & 0.155 \\
\hline PPROM & $17(8.6)$ & $1(7.6)$ & $4(13.7)$ & $5(45.4)$ & $0.03 *$ \\
\hline Birth weight $(\mathrm{g})$ & $3307 \pm 4792.3$ & $3461 \pm 260$ & $3011 \pm 666$ & $3124 \pm 433$ & 0.015 \\
\hline Delivery $<37$ weeks of gestation $n(\%)$ & $18(9.1)$ & 0 & $5(17.2)$ & $3(27.3)$ & 0.08 \\
\hline NICU Admission & $5(3.4)$ & $0(0)$ & $4(16.7)$ & $1(11.1)$ & $0.04^{*}$ \\
\hline Respiratory Distress Syndrome & 0 & 0 & 0 & 0 & 1 \\
\hline Neonatal Sepsis & 0 & 0 & 0 & 0 & 1 \\
\hline
\end{tabular}


and history of presence of PTB. Statistical significance was considered $\mathrm{p}$ values less than 0.05 .

\section{Results}

From a total of 268 women, after lost-to-follow-up patients were excluded, 250 were eligible for analysis in the study. Selected variables according to the groups are presented in Table 1 . Previous abortion $\geq 1$ and previous preterm delivery at 24-34 weeks $\geq 1$ were statistically significantly higher in group 2 when compared with other groups. Coital frequency, cervical length measurements and urinary infection positivity were similar in between the groups. While candida positivity was similar between the groups at the first and second trimesters, it was statistically significantly higher in groups 2 and 4 when compared with other groups.

Maternal and fetal variables according to the groups are shown in Table 2. The number of patients who were diagnosed as having preterm premature rupture of membranes (PPROM) was statistically significantly higher in group 4 when compared with other groups. When birth weight of newborns was compared between the groups, it was statistically significantly higher in groups 1 and 2. Neonatal intensive care unit (NICU) admission was also compared between the groups and the analysis revealed statistically significantly higher number of admissions in groups 3 and 4.

The risk factors for PTB $<37$ weeks of gestation are demonstrated on Table 3. Sexual intercourse during the first trimester, cervical

Table 3. The linear regression model for predictors of Preterm birth $<37$ weeks of gestation

\section{OR Confidence interval p}

\begin{tabular}{|c|c|c|c|}
\hline \multicolumn{4}{|l|}{ First trimester } \\
\hline Sexual intercourse/week & 1.27 & $1.12-1.44$ & $<0.001^{*}$ \\
\hline Urinary infection & & & 0.860 \\
\hline Vaginal symptoms & & & 0.126 \\
\hline Candida positivity & & & 0.320 \\
\hline Nugent score & & & 0.091 \\
\hline Cervical length (mm) & & & 0.393 \\
\hline \multicolumn{4}{|l|}{ Second trimester } \\
\hline Sexual intercourse/week & & & 0.070 \\
\hline Urinary infection & & & 0.346 \\
\hline Vaginal symptoms & & & 0.351 \\
\hline Candida positivity & & & 0.733 \\
\hline Nugent score & & & 0.290 \\
\hline Cervical length (mm) & 5.33 & $1.84-15.41$ & $0.002 *$ \\
\hline History of preterm birth & 6.95 & $1.58-30.54$ & $0.010 *$ \\
\hline
\end{tabular}

length during the second trimester and history of PTB were statistically significant risk factors for PTB $<37$ weeks.

\section{Discussion}

In the present study, we assessed the presence of bacterial vaginosis in the first and second trimesters of pregnancy and evaluated the effects and associations of BV, cervical length, and coital frequency on PTB.

A strong positive correlation was defined between BV and PTB(16). The incidence of PTB among patients with BV was about 1.4-6.9\%(17). Independent from the patients' symptoms, no women with BV gave birth prematurely. Ascending microorganisms may lead to chorioamnionitis, or mucosal permeability may alter due to BV, or local immunity may overrespond, and all of these mechanisms may result in PTB. Also, the earlier the bacterial colonization builds, the stronger the risk of PTB(18). Thus, the frequency of PTB may differ according to the time interval that the vagina, cervix or the fetal parts are exposed to microorganisms. In our study, PPROM was highest in patients who were BV positive both in the first and second trimesters, followed by patients who were BV positive in the first trimester but negative in the second trimester $(45.4 \%$ and $13.7 \%$, respectively).

In the present study, patients with BV were treated during pregnancy. Berghella et al. investigated the association of PTB and sexual intercourse in patients treated for BV(19). Interestingly, their results indicated a decreased incidence of PTB in patients who had intercourse between the second and third trimesters. The authors commented that this was a result of more liberal sexual intercourse in patients without a history of PTB. Nygren et al. and James et al. reported no effects of routine screening and treatment of BV in asymptommatic pregnant women $(4,16)$. Our results showed that even though the incidence of PTB was highest in patients who were BV positive in the first and second trimesters, it did not reach statistical significance. In our multivariate analysis, bacterial vaginosis was not found to be a significant risk factor for PTB, which might be due to the effective treatment of BV. Laxmi et al. researched adverse fetomaternal outcomes in patients with bacterial vaginosis and reported BV as a risk factor for adverse outcomes(5). Our results indicated statistically significantly increased neonatal intensive care unit admission in patients who were BV positive in the first trimester but negative in the second trimester, followed by patients with BV positive both in the first and second trimesters (16.7\% and $11.1 \%$, respectively). Neonatal sepsis and respiratory distress syndrome were not detected in any of the newborns in any groups.

Cervical length assessment has been investigated in the literature and has been used as a useful adjunct for the prediction of PTB(20-22). Mancosu et al. evaluated whether cervical length would shorten more rapidly in patients with BV(23). After adjustment of variables, they reported no effect of BV on cervical shortening. In our study, cervical length measurements in all the 
trimesters in all the groups were not statistically significantly different. Logistic regression analysis revealed a statistically significant effect of cervical length measurement on PTB.

Effect of coitus on PTB has been investigated in the literature. Kurki et al. investigated the association of coitus, bacterial vaginosis, and $\operatorname{PTB}(7)$. They concluded that coitus during pregnancy increased neither bacterial vaginosis nor PTB. Similarly, Yost et al. researched the effect of coitus in early pregnancy on PTB and reported no association between the two parameters $(8)$. Read et al. reported no association between frequent sexual intercourse and PTB, but contrary to previous authors, they reported an increased risk of PTB in the presence of microorganisms $(9)$. In our study, coital frequency had no influence on BV in all groups in all trimesters. Also, only coital frequency in the first trimester was associated with an increased risk of PTB in the regression analysis model, but coital frequency in the second trimester was not associated with an increased risk of PTB. Our results indicated no effect of coitus on PTB after the first trimester.

In conclusion, our results revealed that presence of or treatment of BV did not influence rates of PTB. The probability of PPROM would be higher in patients with BV positive both in the first and second trimesters. Coital frequency in the first trimester, cervical length in the second trimester, and history of PTB are variables that may affect rates of PTB.

Ethics Committee Approval: It was taken.

Informed Consent: It was taken.

Concept: Eray Çalışkan

Design: Yiğit Çakıroğlu

Data Collection or Processing: Emek Doğer, Şule Ylldırım Köpük, Devrim Dündar

Analysis or Interpretation: Eray Çalışkan, Yiğit Çakıroğlu, Şeyda Çalışkan

Literature Search: Yiğit Çakıroğlu, Şule Yıldırım Köpük

Writing: Yiğit Çakıroğlu

Peer-review: Externally peer-reviewed.

Conflict of Interest: No conflict of interest was declared by the authors.

Financial Disclosure: The authors declared that this study has received no financial support.

\section{References}

1. Iams JD. Prevention of preterm parturition. $N$ Engl J Med 2014;370:1861.

2. Oliver RS, Lamont RF. Infection and antibiotics in the aetiology, prediction and prevention of preterm birth. J Obstet Gynaecol 2013;33:768-75.

3. Cunnington M, Kortsalioudaki C, Heath P. Genitourinary pathogens and preterm birth. Curr Opin Infect Dis 2013;26:219-30.

4. Manns-James L. Bacterial vaginosis and preterm birth. J Midwifery Womens Health 2011;56:575-83.

5. Laxmi U, Agrawal S, Raghunandan C, Randhawa VS, Saili A. Association of bacterial vaginosis with adverse fetomaternal outcome in women with spontaneous preterm labor: a prospective cohort study. J Matern Fetal Neonatal Med 2012;25:64-7.
6. McGregor JA, French JI. Bacterial vaginosis in pregnancy. Obstet Gynecol Surv 2000;55( Suppl 1):1-19.

7. Kurki T, Ylikorkala O. Coitus during pregnancy is not related to bacterial vaginosis or preterm birth. Am J Obstet Gynecol 1993;169:1130-4

8. Yost NP, Owen J, Berghella V, Thom E, Swain M, Dildy GA, et al. Effect of coitus on recurrent preterm birth. Obstet Gynecol 2006;107:7937 .

9. Read JS, Klebanoff MA. Sexual intercourse during pregnancy and preterm delivery: effects of vaginal microorganisms. The Vaginal Infections and Prematurity Study Group. Am J Obstet Gynecol 1993;168:514-9.

10. Jones C, Chan C, Farine D. Sex in pregnancy. CMAJ 2011;183:815-8.

11. Bastek JA, Hirshberg A, Chandrasekaran S, Owen CM, Heiser LM, Araujo BA, et al. Biomarkers and cervical length to predict spontaneous preterm birth in asymptomatic high-risk women. Obstetrics and gynecology 2013;122:283-9.

12. Iams JD, Paraskos J, Landon MB, Teteris JN, Johnson FF. Cervical sonography in preterm labor. Obstetrics Gynecol 1994;84:40-6.

13. Martin JA, Hamilton BE, Sutton PD, Ventura SJ, Menacker F, Kirmeyer S, et al. Births: final data for 2005. National vital statistics reports: from the Centers for Disease Control and Prevention, Natl Vital Stat Rep 2007;56:1-103.

14. Nugent RP, Krohn MA, Hillier SL. Reliability of diagnosing bacterial vaginosis is improved by a standardized method of gram stain interpretation. J Clin Microbiol 1991;29:297-301.

15. Iams JD, Goldenberg RL, Meis PJ, Mercer BM, Moawad A, Das A, et al. The length of the cervix and the risk of spontaneous premature delivery. National Institute of Child Health and Human Development Maternal Fetal Medicine Unit Network. N Engl J Med 1996;334:56772.

16. Nygren P, Fu R, Freeman M, Bougatsos C, Guise JM. Screening and treatment for bacterial vaginosis in pregnancy: systematic review to update the 2001 U.S. preventive services task force recommendation. u.s. preventive services task force evidence syntheses, formerly systematic evidence reviews. Rockville 2008.

17. Hoyme UB, Huebner J. Prevention of preterm birth is possible by vaginal $\mathrm{pH}$ screening, early diagnosis of bacterial vaginosis or abnormal vaginal flora and treatment. Gynecol Obstet Invest 2010;70:286-90

18. Desseauve D, Chantrel J, Fruchart A, Khoshnood B, Brabant G, Ancel PY, et al. Prevalence and risk factors of bacterial vaginosis during the first trimester of pregnancy in a large French population-based study. Eur J Obstet Gynecol Reprod Biol 2012;163:30-4.

19. Berghella V, Klebanoff M, McPherson C, Carey JC, Hauth JC, Ernest $\mathrm{JM}$, et al. Exual intercourse association with asymptomatic bacterial vaginosis and Trichomonas vaginalis treatment in relationship to preterm birth. Am J Obstet Gynecol 2002;187:1277-82.

20. Berghella V, Baxter JK, Hendrix NW. Cervical assessment by ultrasound for preventing preterm delivery. Cochrane Database Syst Rev 2013;1:CD007235.

21. Berghella V. Universal cervical length screening for prediction and prevention of preterm birth. Obstet Gynecol Surv 2012;67:653-8.

22. Crane JM, Hutchens D. Transvaginal ultrasonographic measurement of cervical length in asymptomatic high-risk women with a short cervical length in the previous pregnancy. Ultrasound Obstet Gynecol 2011;38:38-43.

23. Mancuso MS, Figueroa D, Szychowski JM, Paden MM, Owen J. Midtrimester bacterial vaginosis and cervical length in women at risk for preterm birth. Am J Obstet Gynecol 2011;204:342. el-5. 